\title{
MODERATING THE IMPACT OF CLIMATE CHANGE ONE UNIVERSITY AT A TIME
}

\author{
ELMER S. SORIANO \\ Civika Asian Development Academy \\ Quezon City, Philippines \\ elmer.soriano@civika.com
}

\begin{abstract}
A sufficient response to the threats posed by climate change presents a leadership challenge proportional in scale with the urgency and complexity of wartime mobilization. The world's 190 million students may be enlisted to respond to such threats through action-research focused on building resiliency. Concepts such as social labs, institutional empathy, and scholarship help reframe the mandates of universities as they respond to climate change, making them platforms for developing leaders and changemakers who will increase the resilience of communities and ecosystems.
\end{abstract}

Keywords: social labs; resiliency; climate change; scholarship

\section{INTRODUCTION}

Disaster preparedness is about people. It's about local government working with the local community and institutions to ensure that this is part of our culture and part of our everyday life .... It's about ensuring that people are prepared, not only with respect to skills but also with respect to a heart that allows them to go beyond themselves-to take care of others: before, during, and after a disaster.-Armin A. Luistro

I was teaching a graduate class that semester when Typhoon Haiyan struck the Philippines in 2013. Far from the hardest hit areas, we kept 
track of the news reports of wind speeds reaching $280 \mathrm{kph}$, making it the most powerful storm in the world to make landfall in recorded history (Yamada \& Galat, 2014). When the typhoon struck, newscasters showed howling winds shattering windows and seawater rushing into the city streets, up until the news feed blacked out as the rising waters damaged news transmission equipment. Electric power lines were downed, mobile communication from the affected areas went silent, and roads were blocked by fallen trees. Only when the connections were gradually restored did the terrible news of massive destruction begin to trickle in: stories of looting, homelessness, lack of water, electricity, and security slowly filled the news. Over several weeks, the government reported 16 million individuals affected, 1.1 million houses damaged (total damages amounted to 1.9 billion USD), and over 6,000 lives lost (NDRRMC, 2013).

As a teacher, I knew this period could provide a powerful learning experience for my students who were completing their coursework on development management. With massive loss of life and damage to property, Typhoon Haiyan surely pushed tens of thousands of vulnerable families further into poverty. Although we were in Manila, some 500 kilometers north of ground zero where Haiyan struck, we could not help but discuss the unfolding of an international humanitarian response over the weeks that followed: different countries pledging support and sending resources, United Nations agencies setting up coordination mechanisms, international humanitarian organization staff arriving by the hundreds. We were spared from the destruction, but instead of just watching passively, how could students learn from and become part of the solution to this massive climate change-induced problem?

\section{LEADERSHIP FOR A CHANGING PLANET}

"Anthropogenic climate change" is the term used to describe human-induced climate change that is affecting the planet (Rosenzweig et al., 2008). From supertyphoons like Haiyan to atypical snowstorms, droughts, and floods, the changing climate requires a planetary-scale response that is difficult to comprehend. Delina (2016) frames the leadership challenge provocatively, entitling his book "Strategies for Climate Mitigation: Wartime Mobilization as a Model for Action?". He presents wartime mobilization as a model to describe the global scale, urgency, and coordination required in the human response to match and deal with climate change. Just as humanity deployed massive resources and energies for World War II, he proposes that governments respond aggressively and quickly by activating similar capacities to reverse climate change, and rightly so-the costs of losing 
this "war" against climate change are not just the direct loss of lives and damage to agriculture due to typhoons or floods, but also secondary effects such as water shortages, migration to cities, refugee crises, and political and armed conflicts as livelihoods become unviable. A Stanford University study estimated that unmitigated climate change could reduce global GDP by $23 \%$ by the year 2100 (Burke, Hsiang, \& Miguel, 2015).

What kind of leadership, then, should humanity muster to adapt to climate change, or even better, reverse its harmful effects? How can leadership be developed and deployed at a scale and potency that is enough to significantly affect the resilience of seven billion people around the globe?

\section{A MILLION TERM PAPERS BY TEN THOUSAND RESILIENCY LABS}

What if universities enlisted students on a massive scale to work on climate change adaptation?

Our planet of seven billion had an estimated 190 million higher education students in 2016, a ratio of one higher education student for every 40 people (British Council, 2012). These 190 million students are in school to learn how to become creative and productive citizens in the future, reading books and writing papers on various subjects. What if each student was assigned to participate in a stream of action-research on local resiliency-related issues in their own towns or communities? Action-research projects would lead students to have local conversations with respondents from various sectors, from farmers to factory workers, parents, and community leaders.

Some leadership thinkers would consider such action-research conversations to be acts of leadership. For instance, Harvard University Professor Ron Heifetz describes adaptive leadership as "the practice of mobilizing people to tackle tough challenges and thrive .... New environments and new dreams demand new strategies and abilities, as well as the leadership to mobilize them" (Heifetz, Grashow, \& Linsky, 2009). By this definition, students would already be deploying acts of leadership if their action-research projects stimulated stakeholders to work on the challenges of climate change that they faced locally.

An alternative label used for leadership is "changemaker." The term changemaker refers to individuals who do not necessarily have formal authority and yet demonstrate the following traits: 
(1) Believe in a responsibility to make positive changes in society.

(2) Have the power and resources to make a difference (tangible and intangible). (3) Take initiative to bring about innovative change, local and systemic. (4) Work with others to maximize impact, working in groups and networks. (5) Know and live authentically according to one's values.

(6) Practice empathy by engaging in another person's world without judgement. (Rivers, Nie, \& Armellini, 2014)

By this definition, a student doing action-research on local resiliency issues would already be behaving as a changemaker.

Electrical engineering student Rikki Macolor of the University of Sto. Tomas in Manila is an example of such a changemaker. Weeks after Haiyan had knocked down electric power lines and left thousands of households without electricity, Macolor started working with a nongovernmental organization (NGO) to help design a solar lantern. It was a simple US\$15 device that combined a small solar panel, a rechargeable battery, a recycled plastic soda bottle, and some wires into a night lamp that could light up a small home for eight hours after exposure to four hours of sunlight. Shortly after, a government agency discovered Macolor's project and decided to mass produce his solar lantern to provide off-grid renewable light to thousands of Haiyan-affected homes (Santos, 2013).

In the class I taught that semester, entitled "Media, Power, and Community Development," we studied how technology and social media could be used to provide global platforms for change, similiar to how TEDx combined videos from hundreds of university talks into one powerful online channel. To link my students to the real-world drama of the Haiyan humanitarian response, I tweaked the curriculum and required my students to design and submit solutions for climate change adaptation via YouTube videos instead of taking a written final exam (their videos can be viewed at http://www.resiliency-lab.com/ idea-generation).

As the world's third most disaster-prone country, the Philippines' 3.5 million college students in over 1,500 colleges and universities could provide a massive stream of resiliency-building projects, just as Macolor and my students did. Our initiatives back in 2013 are part of a small but growing number of social labs that bring the complexity of real-world problems into the classroom.

In his book The Social Labs Revolution, Hassan (2014) describes social labs as follows: 
[They are] platforms for addressing complex social challenges and have three core characteristics: (1)They are social. Social labs start by bringing together diverse participants to work in a team that acts collectively. They are ideally drawn from different sectors of society, such as government, civil society, and the business community. The participation of diverse stakeholders beyond consultation, as opposed to teams of experts or technocrats, represents the social nature of social labs; (2) They are experimental. Social labs are not one-off experiences. They're ongoing and sustained efforts. The team doing the work takes an iterative approach to the challenges it wants to address, prototyping interventions and managing a portfolio of promising solutions. This reflects the experimental nature of social labs, as opposed to the project-based nature of many social interventions; (3) They are systemic. The ideas and initiatives developing in social labs, released as prototypes, aspire to be systemic in nature. This means trying to come up with solutions that go beyond dealing with a part of the whole or symptoms and address the root cause of why things are not working in the first place.

A number of resiliency-oriented labs provide a picture of how these look like in the university setting. The University of Washington Resilience Lab (University of Washington Resilience Lab, 2017) works on stressors affecting the individual and "promotes resilience development while normalizing failure and acknowledging the wide range of hardships our community members have faced and continue to face." It has designed various learning experiences to increase student resilience in the face of failures. The Massachusetts Institute of Technology (MIT) Humanitarian Response Lab focuses on "improving the supply chain systems behind public services and private markets particularly in humanitarian settings." This lab's students and faculty have produced, among others, studies on the logistics of Personal Protective Equipment during the Ebola epidemic in Liberia (Chimnani, Goentzel, \& Hasselberg, 2017) and developed models for scaling up post-harvest crop storage solutions to serve 16,000 farmers in Uganda. The University of Michigan runs a lab program called Beyond Carbon Neutral (Beyond Carbon Neutral, 2017) which works to cool down the planet by developing technologies that increase the rate at which carbon is removed from the planetary carbon cycle.

On the other side of the planet, the Resilient Africa Lab Network (RAN Lab) is a partnership of 18 African universities spread over 13 countries on the continent. In collaboration with George Washington University and Stanford University, the RAN Lab teams have produced solutions such as a low-cost solar-powered irrigation pump system for farmers in Uganda and an Android-based app to educate refugees on reproductive health and other common medical problems in Rwanda (Resilient Africa Network, 2017). 
The Ashoka U Campus Network has a similar university-network strategy. Through a network of forty selected universities, Ashoka $U$ cultivates a campus-wide culture of social innovation by promoting the vision that "Everyone is a Changemaker" (Ashoka U, 2017). Both RAN Lab and the Ashoka U Campus Network attempt to harness the collective brainpower of tens of thousands of students and faculty toward a coherent leadership and changemaking agenda.

\section{TOWARD A SCHOLARSHIP OF RESILIENCY AND LEADERSHIP}

Is it the role of universities to develop students into leaders? Would this not be a distraction from the traditional role of the university of preparing students to enter the workforce? In the face of climate change, can a good university refuse to equip its students with leadership skills to advance resilience in a warming planet? Three perspectives may support the adoption of these efforts in the definition of the university's identity and mandate.

Hambleton's discussion of Boyer's work Scholarship Reconsidered (1990) points out how the type of scholarship demonstrated in social labs is actually not new, but rather a deepening of existing forms of scholarship. Such resiliency-oriented action-research may reflect any one of four overlapping kinds of scholarship. First, the scholarship of discovery describes what is commonly known as research, where faculty and students apply their energies to interrogating the emerging realities of climate change, discovering patterns and models to better understand what is going on. Second, the scholarship of application focuses on the application of knowledge to create solutions to real-world problems. In this type of learning, knowledge is created in the design of solutions, like in the case of Macolor's solar powered lamp, and also as users adopt these solutions. New knowledge emerges from the act of applying knowledge. Third, the scholarship of integration interprets isolated facts and puts them in perspective. In climate change adaptation, students could be investigating the agronomy of droughts in relation to the sociology of farmer education, or the logistics of refugee camps in relation to the technology of health education via Android phones as RAN Lab did in Uganda. Finally, the scholarship of teaching passes on knowledge not just to students but to the broader publics. In the context of climate change adaptation, academe-community dialogues may effectively engage farmers and fisherfolks in learning conversations that help them adapt to climate change, while regular dialogues with the local mayor may help sensitize local municipal policies to community data emerging from students' action research findings (Hambleton, 2014). 
Another way of framing a university's response to climate change is through the concept of "institutional empathy." Empathy reflects the extent to which students and universities embrace the issues of the climate's impact on others as their own. The concept of "institutional empathy" thus proposes that universities and other anchor institutions in cities strengthen the following attributes: civic vision, institutional body language, and community resonance (Jennings et al., 2016). This is important as universities stay in cities for decades or centuries and can thus provide memory and stability across many years of social and climate change.

To build up institutional empathy, university leaders must have civic vision, where the faculty imagine how the university, communities, and city can adapt to climate change. The university's civic vision is made clear not just through declarations in university mandates and documents, but also through a university's institutional body language, where a university conveys its values through its various academic programs, student interventions, extension programs, and community engagements. An empathetic university would use its voice as an analyst and as a representative of various constituents in advancing the public dialogues that influence the policies of the city. An empathetic university would thus demonstrate community resonance, where it can be deeply attuned to the values, tensions, and needs of the community it calls home just as an empathetic individual resonates with the thoughts and feelings of others (Jennings et al, 2016).

The aforementioned universities which have social labs may be thought of as having developed institutional empathy where they embraced resiliency and climate change-related problems as their own, and systematically responded to these from one semester to the next by deploying research and innovation capacities of students and faculty to answer the challenge of resiliency.

\section{MOBILIZING CHANGEMAKERS FOR CHANGING OUR PLANET}

Of the many university-based social labs, the University of Michigan's Beyond Carbon Neutral initiative may be the most ambitious, aiming to reverse global temperature rise by developing solutions to reabsorb carbon from the atmosphere. This goal is definitely audacious, but a similar collaborative effort in response to a planetary-scale environmental problem in the past is showing positive results. In the 1980s, a hole in the ozone layer caused by the introduction of new chemicals into the atmosphere grew to the size of India. Concerted efforts have since led 
to the banning of these ozone-depleting substances, and now the ozone hole is healing and is expected to be fully closed by 2050 .

Many of my students who submitted their ideas via YouTube felt uneasy at first. They were accustomed to having their academic work seen only by teachers, with feedback in the form of check marks and corrections in red ink and ending with the submission of grades. This time around, their work could now be seen by future employers and by others looking for solutions to resilience. I think that exercise changed some of my students' mindsets, even if their proposed designs were not adopted in any major way.

Leadership for resilience requires a shift in mindset from one of helplessness to one of optimism. Universities will have to enable millions of students to believe that anthropogenic climate change can also be positive change that we can study to solve the climate problems that we caused. But first, we have to create that shift in mental models, and we need to start doing that in each classroom to awake the changemaker in each student.

\section{REFERENCES}

Ashoka U. 2017. What we do. Available at http://ashokau.org/about/what-we-do/ (accessed May 15, 2017).

Beyond Carbon Neutral. 2017. Beyond Carbon Neutral. Available at http:// beyondcarbonneutral.org/ (accessed May 16, 2017).

Boyer, E. L. 1990. Scholarship reconsidered: Priorities of the professoriate. Lawrenceville, NJ: Princeton University Press.

British Council. 2012. The shape of things to come: Higher education global trends and emerging opportunities to 2020. Available at https://www.britishcouncil. org/sites/default/files/the_shape_of_things_to_come_-_higher_education_global_ trends_and_emerging_opportunities_to_2020.pdf (accessed May 15, 2017).

Burke, M., Hsiang, S., \& Miguel, E. 2015. Global non-linear effect of temperature on economic production. Nature, 527(7577): 235-239. DOI: 10.1038/nature15725.

Chimnani, J., Goentzel, J., \& Hasselberg, E. 2017. Outbreak and epidemic prevention in Liberia. Available at http://humanitarian.mit.edu/projects/outbreakprevention (accessed May 16, 2017).

Delina, L. L. 2016. Strategies for rapid climate mitigation: Wartime mobilisation as a model for action? New York: Routledge.

Hambleton, R. 2014. From the smart city to the wise city: The role of universities in place-based leadership. Paper presented at Smart City: New Media, Social Participation and Urban Governance, June 5-7. Shanghai, China: Shanghai University. 
Hassan, Z. 2014. The social labs revolution: A new approach to solving our most complex challenges. San Francisco, CA: Berrett-Koehler Publishers.

Heifetz, R. A., Grashow, A., \& Linsky, M. 2009. The practice of adaptive leadership: Tools and tactics for changing your organization and the world. Boston, MA: Harvard Business Press.

Jennings, G., Mann, S., Bryant, F., Kirchman, M., Tisdale, R., Franlde, E., Cullen, J., Konigsberg, J., \& Greenberg, A. 2016. The empathetic museum. Available at http://empatheticmuseum.weebly.com/maturity-model.html (accessed May 16, 2017).

NDRRMC [National Disaster Risk Reduction and Management Council]. 2013. Final report re effects of Typhoon "Yolanda" (Haiyan). Available at http://ndrrmc. gov.ph/attachments/article/1329/FINAL_REPORT_re_Effects_of_Typhoon_ YOLANDA_(HAIYAN)_06-09NOV2013.pdf (accessed May 15, 2017).

Resilient Africa Network. 2017. Ranlab.org. Available at http://www.ranlab.org/ about-us/what-is-ran (accessed May 15, 2017).

Rivers, B. A., Nie, M., \& Armellini, A. 2014. University teachers' conceptions of "changemaker": A starting point for embedding social innovation in learning and teaching. Paper presented at 6th International Social Innovation Research Conference, The University of Northampton, September 1-3. Available at http:// nectar.northampton.ac.uk/6834/.

Rosenzweig, C., Karoly, D., Vicarelli, M. Neofotis, P., Wu, Q., Casassa, G., Menzel, A., Root, T. L., Estrella, N., Seguin, B., Tryjanowski, P., Liu, C., Rawlins, S., \& Imeson, A. 2008. Attributing physical and biological impacts to anthropogenic climate change. Nature, 453(7193): 353-357. DOI: 10.1038/nature06937.

Santos, T. 2013. Thomasian helps light up Tacloban's dark nights. The Varsitarian. Available at http:// http://varsitarian.net/news/20131217/ thomasian_helps_light_up_taclobans_dark_nights (accessed May 15, 2017).

University of Washington Resilience Lab. 2017. Webster.uaa.washington. $\boldsymbol{e d u}$. Available at http://webster.uaa.washington.edu/resilience/ (accessed May 16, 2017).

Yamada, S., \& Galat, A. 2014. Typhoon Yolanda/Haiyan and climate justice. Disaster Medicine and Public Health Preparedness, 8(05): 432-435. DOI: 10.1017/ dmp.2014.97. 